УДК 598.2:591.543.43

Ярослав Омельковець, Катерина Швасвська, Катерина Мельник

\title{
Порівняльне дослідження деяких гематологічних показників птахів різних екологічних груп
}

У роботі порівнюються вміст гемоглобіну, особливості будови еритроцитів, швидкість їх осідання та кількість в 1 мм $^{3}$ крові у семи видів птахів, що належать до різних екологічних груп. Проаналізовано пристосування, які забезпечили збільшення кисневої ємності крові птахів у міру ускладнення локомоції та зростання рухової активності.

Ключові слова: птахи, еритроцити, кров, рухова активність.

Постановка наукової проблеми та її значення. Опанування птахами повітряного простору зумовило потребу в постачанні значних об'ємів кисню до м’язів та швидкому газообміні. Значною мірою це забезпечується морфо-фізіологічними особливостями кровоносної системи представників класу Aves, які добре вивчені та достатньо відображені в навчальній літературі [5; 8]. Значно менше робіт присвячено дослідженню крові птахів, зокрема їх форменим елементам, хоча саме вони забезпечують значну кисневу ємність їх крові .

Аналіз досліджень цієі проблеми дає змогу стверджувати, що сучасні дослідження крові птахів мають здебільшого прикладний - ветеринарний - характер [6; 7; 10]. При цьому гематологічні показники і в нормі, і при патологіях найкраще вивчені у свійських птахів, тоді як у представників дикої орнітофауни вони залишаються не вивченими, хоча викликають інтерес і у ветеринарному, і в еволюційно-морфологічному та морфо-екологічному аспектах.

Мета статті - провести порівняльно-морфологічне дослідження еритроцитів птахів, що належать до різних екологічних груп. Відповідно до мети були поставлені такі завдання: 1) дослідити поздовжній та поперечний діаметри еритроцитів та їх ядер у названих вище видів; 2) визначити об'єм червонокрівців та ядерно-цитоплазматичне співвідношення в них; 3) встановити кількість

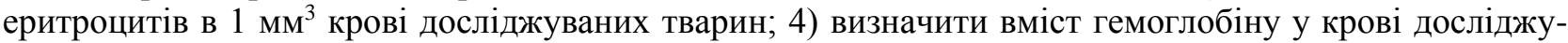
ваних видів; 5) зробити спробу порівняння отриманих показників та інтерпретації виявлених відмінностей у морфо-екологічному аспекті.

Матеріал і методи дослідження. Матеріалом для дослідження слугували мазки крові курки домашньої (Gallus gallus domesticus L.) - 5 екземплярів, ластівки міської (Delichon urbicum L.) 3 екземпляри, голуба сизого (Columba livia L.) - 5 екземплярів, шуліки рудого (Milvus milvus L.) 2 екземпляри, сови сірої (Strix aluco L.) - 3 екземпляри, домашньої качки (Anas platyrhynchos domestica L.) - 5 екземплярів, крижня (Anas platyrhynchos L.) - 4 екземпляри (по 5 мазків із крові кожної досліджуваної особини). Ці птахи належать до різних екологічних груп і відрізняються за локомоторною активністю (зокрема типом польоту), раціоном та способами добування їжі. Так, крижень належить до птахів прісних водойм; ластівка міська - птах відкритих повітряних просторів; голуб сизий - синантропний вид; сова сіра - нічний хижий птах, що тяжіє до заплавних лісів; шуліка рудий - денний хижий птах; курка домашня та качка домашня - свійські птахи.

Забір крові у птахів проводили із підкрилової вени. Фарбування мазків крові здійснювали за Д. Л. Романовським [9].

Вміст гемоглобіну визначали за допомогою фотоелектрокалориметра КФК-3 за загальноприйнятими методиками.

Для вимірювання розмірів еритроцитів використовували лабораторний мікроскоп «Біолам Р-15» та окулярний гвинтовий мікрометр «МОВ-16».

Визначення об'єму еритроцитів здійснювали за формулою: $V=\pi a b^{2} / 6$, де $a-$ поздовжній, $b-$ поперечний діаметри клітини. Аналогічно визначали і об'єм ядра [1]. Для підрахунку ядерноцитоплазматичного співвідношення використовували формулу: $Я Ц C=V я / V u$, де $V я-$ об'єм ядра, $V u-$ об’єм цитоплазми. Об'єм цитоплазми визначали за формулою: $V u=V \kappa-V я$, де $V \kappa-$ об'єм клітини (еритроцита), Vя- об'єм ядра.

(C) Омельковецьь Я., Шваєвська К., Мельник К., 2015 
Співвідношення поздовжнього та поперечного діаметрів еритроцита обчислювали за формулою: $I=a / b$, де $a-$ поздовжній, $b-$ поперечний діаметри клітини.

Кількість еритроцитів у 1 мл крові визначали за допомогою камери Горяєва, а швидкість осідання еритроцитів - за методом Т. П. Панченкова [3; 9].

Виклад основного матеріалу й обгрунтування отриманих результатів дослідження. Як відомо, організм птахів характеризується високою інтенсивністю протікання метаболічних процесів (особливо під час польоту), що, зі свого боку, потребує швидкого надходження значної кількості кисню та своєчасного виведення вуглекислого газу та продуктів обміну речовин [8].

Відомо, що найдосконалішою вважається будова еритроцитів ссавців, які позбавлені ядра i мають форму двоввігнутого диска. Така форма значно полегшує газообмін, адже площа поверхні дископодібного двоввігнутого еритроцита в 1,63 разу перевищує площу поверхні кулі такого ж діаметра. Це не лише прискорює проникнення кисню, а й забезпечує більш повне насичення ним усього гемоглобіну.

Еритроцити досліджуваних тварин істотно відрізняються від червоних кров'яних тілець ссавців тим, що в зрілому стані містять ядро, яке спричиняє двосторонню опуклість клітини і забезпечує більшу тривалість життя цих клітин. Крім того, вони більші за розмірами і мають форму, близьку до овальної (витягнутий сфероїд). Ядро також овальне, воно розміщується уздовж поздовжньої осі клітини (рис. 1-2). Відомо, що площа поверхні витягнутого сфероїда перевищує площу кулі такого ж об'єму. Тому чим витягнутішим буде еритроцит, тим більшою буде площа поверхні, яка припадає на одиницю об'єму і через яку дифундує кисень. Отримані результати засвідчують, що максимальну відносну площу мають еритроцити крижня та качки домашньої, а найменшу - курки домашньої (табл. 1, див. $I_{(a / b))}$.

Цитоплазма еритроцитів фарбується оксифільно, а ядро - базофільно. Контури ядра чіткі, оскільки воно зафарбовується інтенсивніше, ніж цитоплазма (рис. 1-2). На мазках спостерігаються червонокрівці, форма яких дещо відрізняється від овальної. Це вказує на здатність цих клітин змінювати форму, що полегшує їх проходження через капіляри. Трапляються також «монетні стовпчики» - це групи еритроцитів (4-7 клітин), які з’єдналися боковими поверхнями (рис. 1).

У крові досліджуваних видів птахів спостерігається анізоцитоз (табл. 1). Найбільша різниця у розмірах червонокрівців у курки та качки домашньої. У цих тварин максимальний об'єм еритроцитів перевищує мінімальний в 1,7 разу, тоді як у хижих птахів (сова сіра, шуліка рудий) - лише в 1,2 разу.

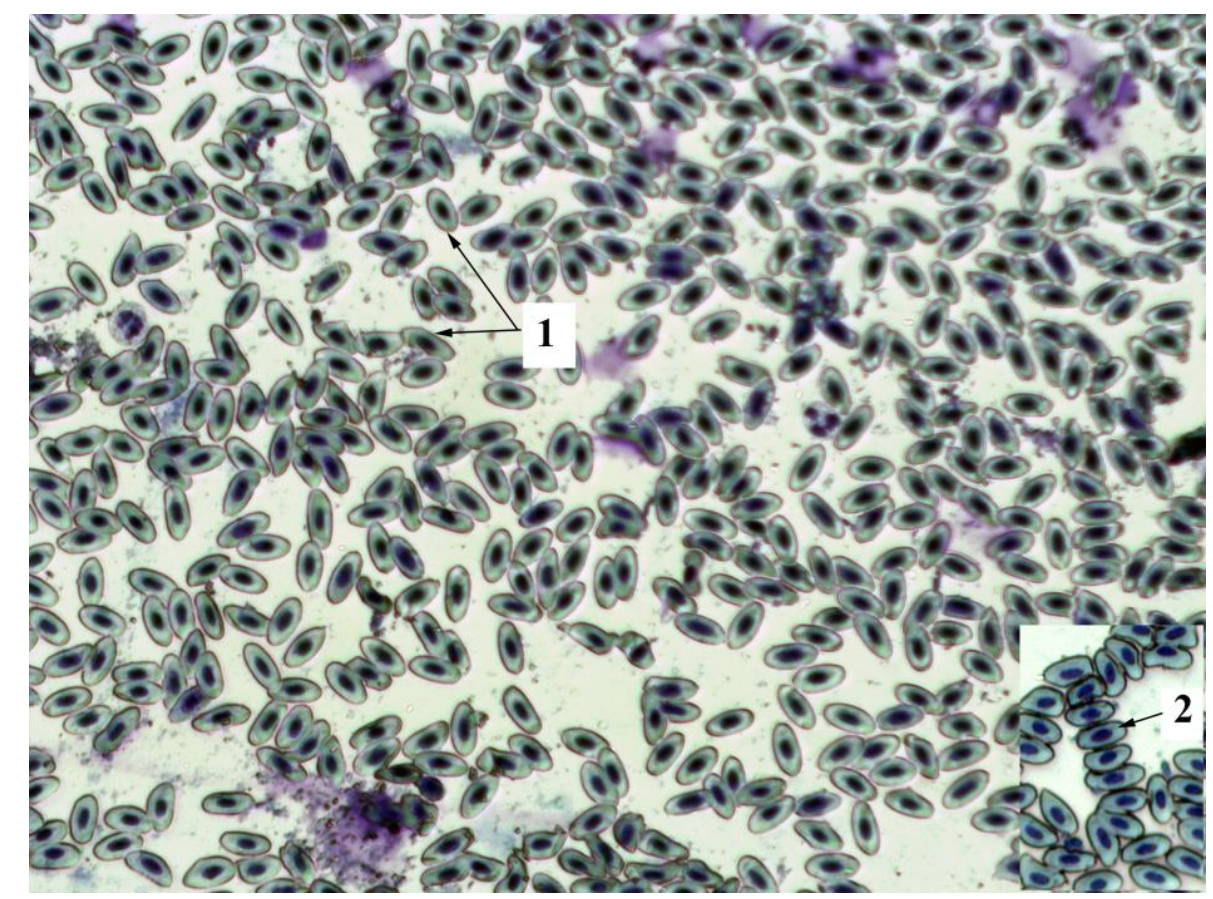

Рис. 1. Еритроцити ластівки міської: 1 - еритроцити; 2 - «монетні стовпчики» (×540) 


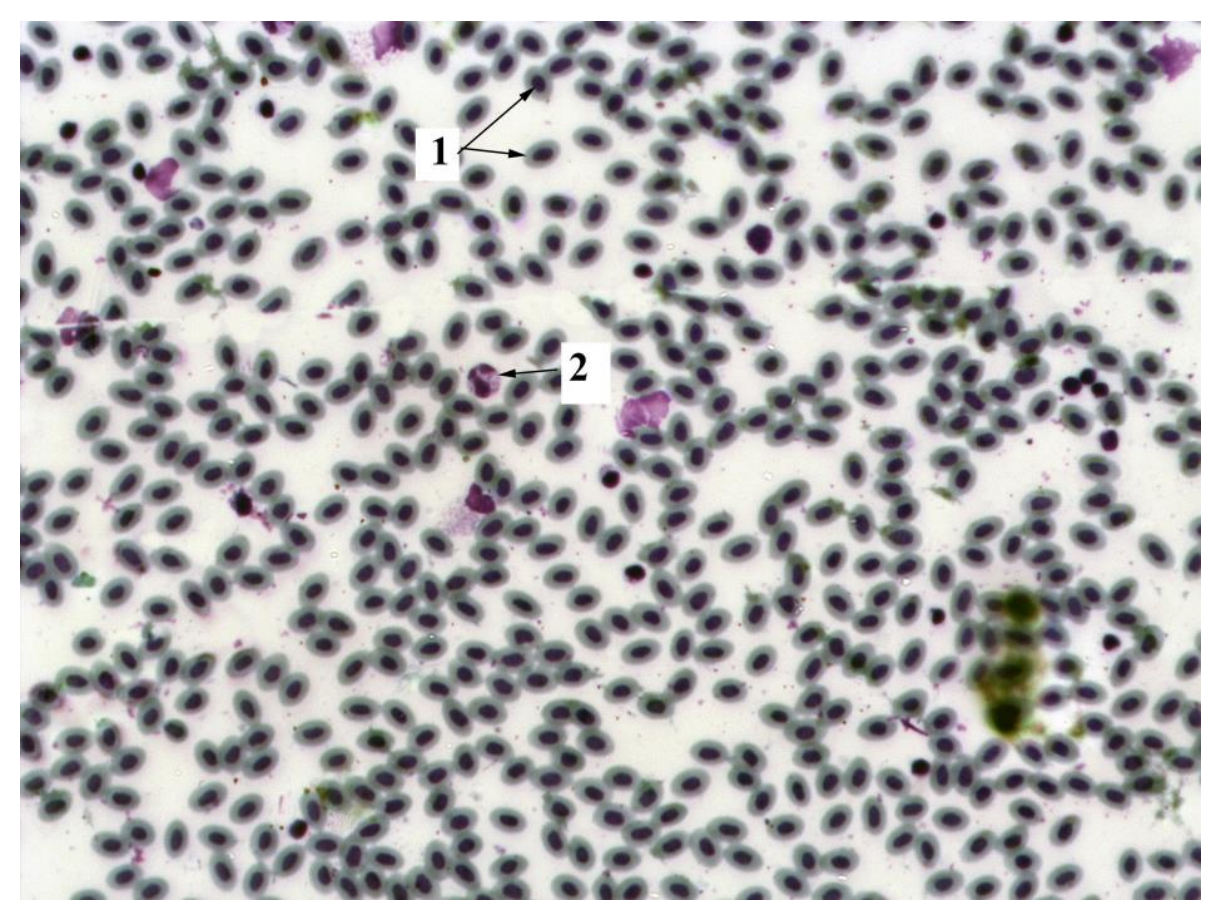

Puc. 2. Формені елементи крові курки домашньої:

1 - еритроцити; 2 - сегментоядерний псевдоеозинофіл $(\times 540)$

Середні розміри еритроцитів зменшуються в такому порядку: крижень, сова сіра, голуб сизий, шуліка рудий, качка домашня, ластівка міська, курка домашня (табл. 1).

Найменші значення ядерно-цитоплазматичного співвідношення ми зафіксували у хижих птахів, а максимальне - у курки (табл.1).

Кількість червоних клітин крові зростає в такому порядку: курка домашня, шуліка рудий, сова сіра, голуб сизий, качка домашня, крижень, ластівка міська (табл. 1). Зазначимо, що в качки домашньої та голуба сизого значення цього показника майже однакові. Вміст гемоглобіну в крові об'єктів дослідження зростає у такій послідовності: курка домашня, шуліка рудий, сова сіра, голуб сизий, ластівка міська, качка домашня, крижень (табл. 1). Отже, можна зробити припущення, що зростання кількості еритроцитів та вмісту гемоглобіну у крові птахів різних видів відбувалося в міру зростання їх рухової активності. Це відповідає теорії паралелізму тканинних структур А. А. Заварзіна, згідно з якою перетворення тканин в еволюції здійснюється відповідно до спільної для цього типу тканин функціонального завдання [3]. Менші, ніж у голуба й ластівки, значення цих показників у шуліки й сови пояснюються, на нашу думку, тим, що у хижаків маховий політ чергується 3 планерним, а частота рухів крилами i, відповідно, інтенсивність роботи м'язів у них менші [2]. Крижень, вміст гемоглобіну в крові якого найвищий серед досліджуваних тварин, характеризується швидким польотом із частими змахами крил [3]. Це зумовлює значну потребу в кисні, особливо під час міграцій. До того ж при пошуках їжі він на тривалий час занурює голову у воду і не здійснює дихальних рухів. Високий вміст гемоглобіну характерний і для домашньої качки, предком якої був крижень, хоча ядерно-цитоплазматичне співвідношення у неї лише дещо нижче ніж у курки.

Максимальну швидкість осідання еритроцитів ми зафіксували в ластівки та голуба (табл. 1), що, очевидно, опосередковано вказує на більший вміст фібриногену в їх крові. У качок значення цього показника найменші серед об'єктів дослідження.

Отримані результати дають змогу припустити, що збільшення кисневої ємності крові птахів досягається такими пристосуваннями:

1) збільшенням відносної площі червоних клітин крові, за рахунок їх видовження (наприклад, крижень, качка домашня, ластівка міська, голуб сизий);

2) зменшенням розмірів червонокрівців, що дало змогу зменшити дифузну відстань, i, відповідно, швидкість насичення цих клітин киснем (наприклад, курка домашня, ластівка міська); 
3) зменшенням розмірів ядра, за рахунок чого збільшився вміст гемоглобіну (наприклад, шуліка рудий, сова сіра);

4) зростанням кількості еритроцитів, що дало змогу підвищити вміст гемоглобіну та сумарно збільшити дифузну площу червонокрівців (ластівка міська, крижень, качка домашня, голуб сизий).

Висновки та перспективи подальшого дослідження. Максимальна кількість прогресивних рис у крові ластівки міської (невеликий об'єм, значна відносна площа та найвища кількість еритроцитів при порівняно невисокому значенні ядерно-цитоплазматичного співвідношення) дала змогу забезпечити найвищу серед досліджуваних тварин сумарну дифузну площу червонокрівців, досить високий вміст гемоглобіну та швидкий газообмін (табл. 1).

Кров крижня характеризується найвищою серед об'єктів дослідження кількістю еритроцитів, найбільшою відносною площею їх поверхні, максимальним вмістом гемоглобіну та порівняно невисоким значенням ядерно-цитоплазматичного співвідношення.

Прогресивними рисами будови еритроцитів хижих птахів є найменше серед досліджуваних тварин ядерно-цитоплазматичне співвідношення та значна відносна площа.

Розміри еритроцитів курки домашньої найменші серед об'єктів дослідження (табл. 1). Однак будову цього виду прогресивною вважати не можна через високе ядерно-цитоплазматичне співвідношення. Вміст гемоглобіну в крові курки домашньої найнижчий серед досліджуваних видів, хоча еритроцити в неї найменші. Це пояснюється їх малою щільністю, великими відносними розмірами ядра та незначною площею приєднання кисню.

\section{Джерела та література}

1. Автандилов Г. Г. Морфология патологии / Г. Г. Автандилов. - М. : Медицина, 1973. -248 с.

2. Жизнь животных. В 7 т Т. 5 / под ред. В. Е. Соколова. - М. : Просвещение, 1989. -612 с.

3. Заварзин А. А. Основы сравнительной гистологии / А. А. Заварзин. - Л. : Изд-во Ленингр. ун-та, 1985. - 400 с.

4. Клинико-лабораторные методы в гематологи / под ред. В. Г. Михайлова, Г. А. Алексеева. - Ташкент : Медицина, 1986. - 198 с.

5. Ковтун М. Ф. Порівняльна анатомія хребетних / М. Ф. Ковтун, О. М. Микитюк, Л. П. Харченко. - Х. : OBC, 2005. $-672 \mathrm{c}$.

6. Липунова Е. А. К методике определения цитокинетических показателей эритроцитарного баланса крови птиц / Е. А. Липунова, М. Ю. Скоркина // Научные ведомости Белгородского государственного университета. Серия: Естественные науки. - 2007. - Т. 5, № 5. - С. 66-69.

7. Морфологические особенности клеток крови птиц [Электронный ресурс] // Научно-исследовательский центр биобезопасности и экологического контроля ресурсов АПК. - Режим доступа : http://biosafetycenter.dp.ua/viddil-fiziology-biohimiya/Biohim/Gematologija_podrobno/Morfologija_kletok_ptic.php

8. Наумов С. П. Зоология позвоночных : учеб. для студ. пед. ин-тов по биолог. спец. / С. П. Наумов. - 4-е изд., перераб. - М. : Просвещение, 1982. - 464 с.

9. Рябушенко Е. Анализы крови у птиц. Основные показатели и их диагностическая значимость [Электронный ресурс] / Е. Рябушенко, М. Шумская // Энциклопедия владельца птицы. - Режим доступа : http://www.mybirds.ru/health/medic/analiz_krovi_pticy.php

10. Чернявских С. Д. Сезонные колебания показателей фагоцитоза эритроцитов и полиморфноядерных лейкоцитов позвоночных животных / С. Д. Чернявских, М. З. Федорова, Е. В. Масленникова // Научные ведомости Белгород. гос. ун-та. Серия : Естественные науки. - 2011. - № 15. - Вып. 16. - С. 68-72.

Омельковец Ярослав, Шваевская Екатерина, Мельник Екатерина. Сравнительное исследование некоторых гематологических показателей птиц разных экологических групп. В работе сравниваются содержание гемоглобина, особенности строения эритроцитов, скорость их оседания и количество в 1 мм $^{3}$ крови у курицы домашней (Gallus gallus domesticus L.), ласточки городской (Delichon urbicum L.), голубя сизого (Columba livia L.), коршуна рыжего (Milvus milvus L.), неясыти (Strix aluco L.), утки домашней (Anas platyrhynchos domestica L.) (кросс «Темп» белорусской селекции), кряквы (Anas platyrhynchos L.). Увеличение кислородной емкости крови птиц обеспечивается такими приспособлениями: уменьшением размеров ядра и увеличением количества эритроцитов, что приводит к увеличению содержания гемоглобина. Скорость насыщения красных клеток крови кислородом возрастает вследствие увеличения их относительной площади, уменьшения диффузного расстоянии и увеличения суммарной площади эритроцитов.

Ключевые слова: птицы, эритроциты, кровь, двигательная активность.

Omelkovets' Yaroslav, Shvayevska Kateryna, Mel'nik Kateryna. The Comparative Research of Some Hematological Indicators in Birds of Different Ecological Groups. The article deals with the comparison of the hemoglobin contents, the structural features of the erythrocytes, its suspension stability and red count in $1 \mathrm{~mm}^{3}$ of 
blood in chicken (Gallus domesticus L.), chimney swallow (Delichon urbicum L.), rock-pigeon (Columba livia L.), red kite (Milvus milvus L.), tawny owl (Strix aluco L.), mallard (Anas platyrhynchos domestica L.), mollard duck (Anas platyrhynchos L.). The increasing of the blood oxygen capacity in birds is provided by such adaptations: decreasing the nuclear size and increasing the number of erythrocytes, that leads to the increasing the cellular hemoglobin content. The saturation rate of red blood cells by oxygen increases due to the increasing of their relative areas, reducing of diffuse distance and increasing of total area of erythrocytes.

Key words: birds, erythrocytes, blood, physical activity.

Стаття надійшла до редколегії 25.02.2015 p.

УДК: 595.771:582.28

\section{Вадим Теплюк Наталія Кубат}

\section{Біоекологічний аналіз метеликів родин Papilionidae, Pieridae i Nimphalidae міста Буська та його околиць}

У межах м. Буська та його околиць зареєстровано 31 вид денних метеликів із родин Рapilionidae, Pieridae i Nimphalidae. Встановлено біотопічну приуроченість, трофічні зв'язки гусені, періоди льоту імаго, особливості зимівлі та розвитку окремих видів.

Ключові слова: метелики, гусінь, біотоп, ліси, луки, агроценози.

Постановка наукової проблеми та їі значення. Відіграючи важливу роль в екосистемах, передусім як фітофаги й запилювачі, денні лускокрилі мають особливе наукове й естетичне значення. Серед них $\epsilon$ шкідники, які в окремих випадках можуть завдавати значних збитків сільському господарству, хоча кількість таких видів невелика [8]. Ці метелики становлять лише $10 \%$ загального видового складу Lepidoptera та займають далеко не всі екологічні ніші, однак вони є хорошою індикаторною групою наземних екосистем [3]. Водночас ця група комах досить вразлива до антропогенних впливів, тому і становить значну частку в списках рідкісних та видів на межі зникнення безхребетних тварин тих чи інших територій $[8 ; 10]$.

Оскільки денні лускокрилі в межах м. Буська (Львівської області) та його околиць досліджені недостатньо, тому це питання певною мірою залишається відкритим та має важливий теоретичний $\mathrm{i}$ практичний інтерес.

Аналіз досліджень цієї проблеми. Вивчення вказаних метеликів на території України триває понад 200 років. Першим дослідником цієї групи комах вважається Яков Гюбнер, який загалом зареєстрував 539 видів лускокрилих в околицях Немирова (серед них 48 видів Papiliones). У 1865 p. опублікована праця Новицького «Метелики Галичини», у якій відзначено 126 видів денних метеликів. У першій половині XX ст. Л. А. Шелюжко та М. С. Образцовий описали 157 видів цих метеликів для території України [8]. 3 другої половини XX ст. лепідоптерологи основну увагу приділяли фауністичному складу [6; 9], розробляли таблиці для визначення [5], розкривали особливості біології та поширення окремих видів цих комах [7].

У XXI ст. дослідження лускокрилих України спрямовані в основному на вивчення їх екології та зосереджені в межах двох районів - Поділля і Карпат, де працює Ю. В. Канарський [3; 4] та Дніпропетровщини, де цими питанням займається К. К. Голобородько [1;2].

Мета і завдання статті. В основу нашого дослідження лягло уточнення видового складу, встановлення відносної чисельності, а також комплексний біоекологічний аналіз (біотопічна приуроченість, трофічні зв'язки гусені, період льоту імаго, особливості зимівлі та кількість генерацій на рік) денних метеликів родин Papilionidae, Pieridae та Nimphalidae м. Буська та його околиць, що в подальшому

(C) Теплюк В., Кубат Н., 2015 